\title{
Violent deaths of media workers associated with conflict in Iraq, 2003 to 2012
}

\section{Background}

The violent death of media workers is a critical issue worldwide, especially in areas of political and social instability. Such deaths can be a particular concern as they may undermine the development and functioning of an open and democratic society.

\section{Methods}

Data on the violent deaths of media workers in Iraq for ten years (2003 to 2012) were systematically collated from five international databases. Analyses included time trends, weapons involved, nationality of the deceased, outcome for perpetrators and location of death.

\section{Results}

During this ten-year period, there were 199 violent deaths of media workers in Iraq. The annual number increased substantially after the invasion in 2003 (peaking at $n=47$ in 2007) and then declined ( $n=5$ in 2012). The peak years (2006-2007) for these deaths matched the peak years for estimated violent deaths among civilians. Most of the media worker deaths (85\%) were Iraqi nationals. Some were killed whilst on assignment in the field (39\%) and $28 \%$ involved a preceding threat. Common perpetrators of the violence were: political groups (45\%), and coalition forces (9\%), but the source of the violence was often unknown (29\%). None of the perpetrators have subsequently been prosecuted (as of April 2014). For each violent death of a media worker, an average of 3.1 other people were also killed in the same attack (range 0-100 other deaths).

\section{Discussion}

This analysis highlights the high number of homicides of media workers in Iraq in this conflict PeerJ reviewing PDF | (v2014:01:1387:2:0:CHECK 29 Apr 2014) 
period, in addition to the apparently total level of impunity. One of the potential solutions is likely to be establishing a functioning legal system that apprehends offenders and puts them on trial. The relatively high quality of data on violent deaths in this occupational group, suggests that it could act as one sentinel population within a broader surveillance system of societal violence in conflict zones. 


\section{Authors}

3 Lucie Collinson, Research Fellow, $\mathrm{MBChB} * \dagger$

4 Nick Wilson, Associate Professor, $\mathrm{MBChB} *$

5 George Thomson, Research Associate Professor, $\mathrm{PhD}$ *

6 * Department of Public Health, University of Otago Wellington, PO Box 7343 Wellington, New

7 Zealand.

8 †Corresponding author. Email: lucie.collinson@otago.ac.nz; Phone: +447855506181 Address: as 9 above 


\section{Introduction}

Violence is a preventable cause of injuries and deaths as well as being a threat to human security (Owen 2004). It is also a recognised dimension for measuring state governance (Kaufmann et al. 2011). Data on violent deaths can refer to either interpersonal or collective violence (Dahlberg \& Krug 2002; Zwi et al. 2002), and may be an indicator of the level of conflict at a societal level.

More specifically, the violent deaths of media workers is a major issue worldwide, with persistent high levels of impunity - meaning the perpetrators are rarely prosecuted (Riddick et al. 2008). Furthermore, media worker freedom and safety is of particular concern in settings of political and social instability (Krueger 2008). Media workers may be targeted because of their work by direct acts of violence and threats of violence during times of social and political breakdown and war, or be harmed as bystanders from more general violence.

Violent deaths of media workers can be studied in the Iraq, a setting with high levels of societal violence. The invasion of Iraq in 2003 was associated with a notable increase in the number of media workers suffering violent deaths (Wilson \& Thomson 2007) as well as an increase in civilian deaths (Roberts et al. 2004). During the years 2003 to 2008, it was the country with the highest number of media workers killed, and for the period 2006 to 2007 it contributed between $36 \%$ to $54 \%$ of media workers deaths worldwide (CPJ 2012; IPI 2012; RSF 2012). Iraq continues to score highest on the Committee to Protect Journalists' (CPJ) impunity index each year since it was first published in 2008 (CPJ 2014). This index ranks countries based on the proportion of violent deaths of media workers where perpetrators are not prosecuted.

Given this background, we aimed to study the violent deaths of media workers in Iraq, determine the scope of ways to prevent this problem, and evaluate whether deaths in this occupational group could be used as a sentinel surveillance of societal violence in conflict zones. This latter issue is particularly relevant to Iraq, where there have been large variations in estimates of the scale of civilian deaths by various studies and surveillance systems data (Burkle \& Garfield 2013) (Burnham et al. 2006; Roberts et al. 2004) (Hicks et al. 2011a; Hicks et al. 2011b; Hicks et al. 2009) (Hagopian et al. 2013).

\section{Methods}

Definitions: As per a previous study in which two of the authors were involved (NW and GT) (Riddick et al. 2008), we defined media workers as being those who collect or present information for public use (e.g., media presenters and translators), and those who make decisions about what information is collected and presented to the public (e.g., editors). A number of related occupations were excluded, including drivers and security guards associated with media companies. Violent death was defined as intentional violence or as a result of being in the vicinity of fighting (e.g., death from cross-fire or air strikes by military forces). To ensure a conservative estimate, we excluded violent deaths where there was insufficient evidence from the databases that the death was in anyway related to the person being a media worker or conducting their job as a media worker, for example if the body was found in a morgue and the circumstances of death were unclear (Table 1). Also excluded were suicide of the media worker and cases where a media worker was missing and presumed dead, but where a body was never found. 
Data collection: Data were collected for the ten-year period 2003-2012, from five databases used in a previous study (Riddick et al. 2008) that were compiled by: the Committee to Protect Journalists (CPJ) (CPJ 2012) Reporters Without Borders (RSF-Reporters Sans Frontières) (RSF 2012) United Nations Educational, Scientific and Cultural Organisation (UNESCO) (UNESCO 2012) the International News Safety Institute (INSI) (INSI 2012) and the International Press Institute (IPI) (IPI 2012).

Violent deaths of named individuals were only included where they were documented in two or more of the five databases. Details for each death were collected from each of the databases. Where necessary an internet search (using Google) was performed to obtain further information. Included and excluded cases were reviewed at the end of the data collection by two of the authors, to ensure that criteria had been applied consistently. Where specific nationality was not identified in the searchers, media workers were considered to be nationals of Iraq if there was evidence of long-term residence, local extended families, or local hometown provided by the source organisations. Where sex was unknown $(n=21)$, names were checked with a fluent Arabic speaker (whose first language was Arabic).

Media workers were often reported as having more than one occupation within the domain of media work. We recorded the occupation they were doing at the time of death, or, if it was not clear, we used the occupation they were documented as working at most commonly. The perpetrators of the violence from which the media worker died were recorded where these data were available from the source organisations, and whether or not they had been brought to justice. Data on perpetrators were predominantly only available from CPJ and were collected as coded by CPJ. Political groups included non-governmental militias and non-specified 'armed men' or 'insurgents'. Iraqi Government forces are coded as militia.

Data were collected on the number of others killed or injured in the same attack as each violent death of a media worker from each of the five databases. Where there was more than one media worker killed in the same incident, the numbers of others killed and injured alongside were only counted once.

Data analysis: Basic descriptive analysis was performed along with time trends. The ten year time period was separated into two five-year periods; firstly 2003-2007 from the year of the United States (US) led invasion up to and including the "surge" of coalition military activity in Baghdad when 30,000 additional US troops entered Iraq. The second period was 2008-2012 and covered the growing autonomy of the Iraqi Government and institutions. It included the final year of coalition troop withdrawal (2011).

We used a Poisson regression in the statistical software package Stata (v 11) to calculate the confidence intervals for the ratio of counts of civilian to media worker deaths by year (thus Poisson variation is considered for the ratio of counts between these groups, rather than the ratio of the rates of events, since we had no denominator).

To provide additional context, the BBC news agency's timeline for chronology of key events in Iraq, along with data from the New York Times, were used to inform the interpretation of the time series analysis (BBC 2012; Livingston et al. 2011). 


\section{Results}

This analysis identified 199 violent deaths of media workers in Iraq during 2003-2012 that met our definitions. This compares with 231 deaths recorded by CPJ (including both confirmed and unconfirmed judgements of whether the death was related to the media worker's work), 190 by RSF, 190 by IPI, 158 by INSI and 116 by UNESCO.

In the five databases reviewed, there were an additional 107 deaths of media workers that were excluded from our analysis (Table 1). The major reasons for these exclusions were: (i) for 73, the media worker death only being recorded in one of the five databases (68\%); (ii) for five, the individual not being definitively identified as being a media worker (5\%); (iii) for 16, not having any names identified (15\%); or (iv) for eight, only having one name identified ( $8 \%$ ).

Annual trends: The annual number of violent deaths in media workers rose from 15 in 2003 to 47 in 2007 (the peak year) dropping back to 5 in 2012 (Figure 1). The peak years (2006-2007) for these deaths matched the peak years for estimated civilian fatalities (Figure 3 ). There were no media worker deaths recorded for Iraq in 2002 in a previous study (Wilson \& Thomson 2007), and in our further examination of the databases collecting data at this time.

The media workers killed were more likely to be Iraqi $(85 \%, n=169 / 199)$ than foreign nationals (Table 2). Of those where the foreign nationality was known, most $(57 \%, 8 / 14)$ were from OECD countries (Table 2).

A majority (62\%) of those dying worked for Iraqi media agencies. This proportion increased over time, relative to the first five-year time period but not at a statistically significant level $(\mathrm{p}=0.053)$ (Figure 1). Out of the remaining 38\% not working for Iraqi media agencies, $65 \%$ worked for employers from OECD countries and 35\% for employers from other Middle Eastern countries. Of the OECD countries, the USA and UK were most highly represented at $39 \%$ and $35 \%$ respectively (Table 2 ).

Main associations and risk factors: The major direct cause of these violent deaths was gunfire $(68 \%)$, followed by suicide bombs $(8 \%)$ and non-suicide bombs (6\%) (Table 2). Gunfire remained the leading cause of death across both time periods with minimal variation in proportions. Deaths from grenades, missiles, landmines or airstrikes only occurred in the earlier time period (2003-07), whilst the proportion of vehicle bombs as cause of death increased significantly in the latter time period, relative to the first five-year time period $(p<0.001)$.

It was difficult to classify the extent to which the media workers were intentionally sought out and killed in highly targeted attacks, versus being killed when working in the field (e.g., in a bomb blast or in cross-fire). Nevertheless, some suggestion comes from the location data in Table 2. It shows that $39 \%$ of media workers were killed whilst on assignment in the field (39\%), but most (50\%) died in other settings such as whilst travelling (other than on assignment) (24\%), or at home (12\%) (often in front of family members). Furthermore, some of the media workers killed were reported as being tortured (5\%) and taken captive (13\%) prior to death, although this was often unknown (56\% and 55\% respectively). Media workers, their families or their employers received threats to their safety in $28 \%$ of cases.

Half of the media workers who died were media presenters (reporters, correspondents, broadcasters or news presenters) $(50 \%)$, followed by camera operators $(19 \%)$, and editors $(14 \%)$. 
The proportion of media workers killed who were presenters significantly increased in the latter five-year time period relative to the first $(\mathrm{p}=0.02)$.

Perpetrators and justice: Almost one-third (29\%) of the perpetrators of the violent act in which the media worker died were unknown, while almost half (45\%) were political groups. For all the violent deaths during the 10-year period, there has been no evidence of a consequent prosecution of perpetrators by legal authorities (as of April 2014) (CPJ 2014). For one attack where three media workers were killed, a group of nine men were detained by the police as suspects but no further investigation was reported.

Others killed or injured alongside the media worker: Over the 10-year period, a total of 511 civilians were reported to have been killed in the same attack in which a media worker died. Furthermore, another 426 were injured in these attacks (Table 4 and Figure 2). For each media worker killed, 3.1 civilians were killed on average in the same attack (range: $0-100$ ) and a further 2.6 civilians were injured (range: $0-180$ ).

An example of two violent deaths of media workers where 10 other civilians were killed in the same attack is when Namir Noor-Eldeen and Saeed Chmagh were killed by airstrike from coalition forces whilst on assignment in New Baghdad on July 12 2007. A video of this incident is available on YouTube https://www.youtube.com/watch? $\mathrm{v}=5 \mathrm{rXPrfnU} 3 \mathrm{G} 0$.

The ratio of civilian to media worker deaths: Using counts of civilian deaths from violence from the Iraq Body Count (http://www.iraqbodycount.org/), the number of civilian deaths per media worker death increased from 412 (95\% CI: 284 - 597) in 2004 to 1276 (95\% CI: $479-3400)$ in 2009 where it peaked (Table 3).

Relating annual trends to key socio-political events: The annual number of violent deaths of media workers increased substantially after the military invasion in 2003 (it was zero in 2002, see above). The peak years of these deaths coincided with the years of the highest levels of violence in Iraq (2006 and 2007) when explosive incidents were at their height (Table 4). The peak year of these deaths (and others injured alongside each death) also coincided with the military surge with an additional 30,000 US troops entering Iraq. The number of violent deaths of media workers then declined in the subsequent period where the war changed from US vs Iraqi to a largely civil war with the departure of coalition forces from 2009 onwards.

\section{Discussion}

Main findings: This analysis confirms the substantial size of the problem of violent deaths of media workers in Iraq. Not only were 199 media workers killed (between 2003 and 2012), but there were a further 511 civilians killed and 426 injured in the same attacks. This picture adds evidence for the high risk of the media worker occupation in politically unstable states (Riddick et al. 2008).

These data also indicate a marked increase in the numbers of media workers dying violently from the time of the invasion of Iraq (2003) and a decrease at the time that coalition forces withdrew. The peak years (2006-2007) for violent deaths in media workers matched the peak years for estimated civilian fatalities, with similar time trends overall. 
171 There are variable levels of evidence around the extent of intentional targeting of these media 172 workers because of their occupation, but in some cases it is fairly suggestive e.g., being killed in 173 their office at work and having had preceding threats.

174 The risks for media workers may be heightened by the apparent high levels of impunity for their 175 killers (Khan 2007). Indeed, in our study we found no evidence that any of perpetrators of the 176 violent deaths of media workers recorded in Iraq during this period have been prosecuted by legal 177 authorities. Improving the safety for media workers is likely to be imperative for the existence of 178 a free press which is a fundamental constituent to a functioning democracy. Journalism is a vital 179 component to emerging democratic societies (McNair 2009) and a A free press is associated with 180 lower levels of corruption (Brunetti \& Weder 2003). A restricted press not only precludes the other injustices to coexist. The source organisations CPJ and IPI call for proper enforcement of the law to protect journalists whilst RSF contests laws that restrict freedom of information. INSI urges for safer working in hostile areas and provides free safety training courses for journalists worldwide. UNESCO condemns the killing of journalists and hosts World Press Freedom Day.

The similarity in trends of violent deaths of civilians and media workers suggests that deaths in this occupational group could potentially contribute as a sentinel surveillance system. For example, as one component of a broader surveillance system for monitoring societal violence in conflict zones. A particular advantage of this occupational group for this role would be the relatively reliable data on each violent death. Also, these deaths are likely to highlight the difficulties in achieving non-corrupt and democratic institutions in the conflict area. The disadvantages are that these deaths may not be fully representative of trends in other civilian deaths. This is because of the unique aspects of the occupation (e.g., travel to conflict areas) but also because media workers may be more readily able to modify their behaviour over time to reduce risk compared to other citizens (e.g., wearing body armour and hiring protection). The crude nature of only using data from media workers for sentinel surveillance is also suggested in our data where the ratio of civilian deaths to media workers deaths fluctuated markedly over the 10 year period (Table 3 ), as did the range of others killed or injured alongside the media workers (ranging from 0 to 100).

Study limitations: The study was dependent on the sensitivity and the accuracy of the five main databases used in documenting violent deaths of media workers. Overall the CPJ database provided more information on each of the variables collected than the other four databases. Often the data from the other databases was very similar and sometimes had identical wording. The CPJ provided most of the information on impunity, perpetrators and whether the media worker was tortured, taken captive or threatened prior to being killed. The coding of perpetrators collected from the CPJ database appears to be relatively simplistic. It does not take into account multiple perpetrators, such as the occasional example of coalition forces backing Iraqi Government forces. However, validity checks using the search engine Google did not indicate that there was any significant concern with the accuracy of coding in the CPJ database.

Four of the databases we used (CPJ, RSF, IPI, INSI) are compiled by international nongovernmental organisations, and one is an official international organisation (UNESCO) with an interest in communication, media freedom, or media safety. CPJ, RSF, and IPI all have local employees or volunteers who do independent research, fact-finding missions and talk to people in the field (often to other media workers). The latter three organisations were also honoured by the U.S. National Television Academy at the News and Documentary Emmy awards in 2006. INSI 
do not document how it monitors media worker casualties, but they do however have links to the International Federation of Journalists. UNESCO also does not document how their list of media workers killed is compiled.

Factors that may increase the likelihood of violent deaths of media workers also increase the difficulties in gathering data on such deaths. Therefore it is possible that there is under-recording of these deaths, and that some of the cases that we excluded $(n=107)$ are indeed of media workrelated deaths. Because of our inclusion criteria, requiring the violent death to be recorded in more than one database, and excluding those where there was insufficient evidence to suggest that the death was work related, the total is likely to be conservative.

In this study there were inadequate denominator data to allow calculations of the rate of violent death per 1000 media workers in Iraq. This problem of inadequate denominator data has been reported in other such studies (Taback \& Coupland 2006), and indeed developing a register of media workers in a country like Iraq could pose actual risks to such workers.

A further limitation is that our source for civilian deaths, the Iraq Body Count, is likely to be underrepresenting death rates (Carpenter et al. 2013; Hagopian et al. 2013). In addition the Iraq Body Count data includes media worker deaths among civilian deaths and these were not removed from the civilian death counts. Therefore the true ratios of violent civilian deaths to violent deaths of media workers would be slightly lower than the ratios presented here, as some of the media worker deaths in the numerator (data collected from the five databases) would also be in the denominator (Iraq Body Count data) (Table 3).

Implications for further research: Further studies are needed to obtain a better understanding of the epidemiology of the violent deaths of media workers in Iraq and other conflict zones. In particular, the priority for research in such settings would be to establish plausible denominator populations of media workers - ideally both indigenous and those visiting on assignment from other countries.

International organisations could also potentially improve collaboration to limit the number of databases collecting information on these deaths, while establishing systems that collect more indepth information (for example to better clarify if the media worker was specifically targeted and if perpetrators were processed by the justice system).

Strengthening data collection on violence has been nominated as a goal by the WHO Global Campaign for Violence Prevention 2012-2020 (Butchart et al. 2012). Given the lack of reliability of government reports related to civilian deaths, where gaps in mortality and morbidity data that relate to violence exist, there is a need to coordinate what resources are currently available and utilise them. In some cases there is a need to establish independent surveillance systems of violent death in conflict zones.

\section{Conclusions}

252 This paper highlights the high number of violent deaths of media workers in Iraq in this conflict 253 period, in addition to the high levels of impunity for perpetrators. Many others also die and are 254 injured when a media worker is killed in an attack. This situation suggests a need for urgent 255 preventative measures to protect the safety of media workers (for example by having an effective 
policing and legal system). Collecting data on media workers could also potentially be a sentinel surveillance system that contributes to a broader surveillance system of societal violence in conflict zones.

\section{Acknowledgements}

We thank those organisations that have collected and made publicly available data on violent deaths of media workers (see Methods). We thank Dr James Stanley for his assistance with some of the statistical analysis and Dr Sarah Al Youha for her assistance with identifying the gender of the first names of media workers where it was not recorded.

\section{References}

BBC. 2012. Iraq profile - timeline. A chronology of key events: The British Broadcasting Corporation (BBC). http://www.bbc.co.uk/news/world-middle-east-14546763

Brunetti A, and Weder B. 2003. A free press is bad news for corruption. Journal of Public Economics 87:1801-1824.

Burkle F, Jr., and Garfield R. 2013. Civilian mortality after the 2003 invasion of Iraq. Lancet 381:877-879.

Burnham G, Lafta R, Doocy S, and Roberts L. 2006. Mortality after the 2003 invasion of Iraq: a cross-sectional cluster sample survey. Lancet 368:1421-1428.

Butchart A, Mikton C, and Kieselbach B. 2012. Violence Prevention Alliance Global Campaign for Violence Prevention: Plan of Action for 2012-2020. Global Campaign for Violence Prevention. Geneva, Switzerland: World Health Organization Violence Prevention Team on behalf of the Violence Prevention Alliance.

Carpenter D, Fuller T, and Roberts L. 2013. WikiLeaks and Iraq Body Count: the sum of parts may not add up to the whole-a comparison of two tallies of Iraqi civilian deaths. Prehospital and Disaster Medicine 28:223-229.

CPJ. 2012. Committee to Protect Journalists Defending Journalists Worldwide. New York Committee to Protect Journalists http://www.cpj.org/

CPJ. 2014. CPJ's 2014 Impunity Index. Getting Away With Murder. New York Committee to Protect Journalists.

https://www.cpj.org/reports/2013/05/impunity-index-getting-away-withmurder.php\#index

Dahlberg LL, and Krug EG. 2002. Violence - a global public health problem. In: Krug E, Dahlberg LL, Mercy JA, Zwi AB, and Lozano R, editors. World Report on Violence and Health. Geneva, Switzerland: World Health Organization. p 3-21. http://whqlibdoc.who.int/publications/2002/9241545615 eng.pdf

Hagopian A, Flaxman AD, Takaro TK, Esa Al Shatari SA, Rajaratnam J, Becker S, Levin-Rector A, Galway L, Hadi Al-Yasseri BJ, Weiss WM et al. 2013. Mortality in Iraq associated with the 2003-2011 war and occupation: findings from a national cluster sample survey by the university collaborative Iraq Mortality Study. PLOS Medicine 10:e1001533.

Hicks MH, Dardagan H, Bagnall PM, Spagat M, and Sloboda JA. 2011a. Casualties in civilians and coalition soldiers from suicide bombings in Iraq, 2003-10: a descriptive study. Lancet 378:906-914. 
Hicks MH, Dardagan H, Guerrero Serdan G, Bagnall PM, Sloboda JA, and Spagat M. 2011 b. Violent deaths of Iraqi civilians, 2003-2008: analysis by perpetrator, weapon, time, and location. PLOS Medicine 8:e1000415.

Hicks MH, Dardagan H, Serdán GG, Bagnall PM, Sloboda JA, and Spagat M. 2009. The Weapons That Kill Civilians - Deaths of Children and Noncombatants in Iraq, 20032008. The New England Journal of Medicine 360:1585-1588.

INSI. 2012. Casualties. International News Safety Institute. Brussels: International News Safety Institute. http://www.newssafety.org/

IPI. 2012. International Press Institute Defending Press Freedom for over 60 Years Vienna, Austria International Press Institute. http://www.freemedia.at/home.html?no cache=1

Iraq Body Count (2013) Documented civilian deaths from violence 2003-2012. http://www.iraqbodycount.org/ (Accessed 30 April, 2013).

Kaufmann D, Kraay A, and Mastruzzi M. 2011. The Worldwide Governance Indicators (WGI) project. In: Group. TWB, editor: Brookings Institution. World Bank Development Research Group. World Bank Institute. http://info.worldbank.org/governance/wgi/index.asp

Khan AW. 2007. Pervasive climate of impunity makes journalists easy targets. In: UNESCO, editor. Press freedom safety of journalists and impunity United Nations Educational, Scientific and Cultural Organisation http://unesdoc.unesco.org/images/0015/001567/156773e.pdf

Krueger PM. 2008. The social and political functioning of states and the homicide of media workers. Journal of Epidemiolgy \& Community Health 62:666-667.

Livingston I, O'Hanlon ME, and Unikewicz A. 2011. States of Conflict: A Final Update. The New York Times 18 December http://www.nytimes.com/2011/12/19/opinion/states-of-conflicta-final-update.html? $\mathrm{r}=0$

McNair B. 2009. Journalism and Democracy. In: Wahl-Jorgensen K, and Hanitzsch T, eds. The Handbook of Journalism Studies. New York: Routledge.

O'Hanlon ME, Livingston I (2011) Iraq Index. Tracking Variables of Reconstruction $\&$ Security in Post-Saddam Iraq: Brookings Institution. http://www.brookings.edu/ /media/Centers/saban/iraq\%20index/index201012 30.PDF

Owen T. 2004. Challenges and opportunities for defining and measuring human security. In: Vignard K, editor. Disarmament Forum Human Rights, Human Security and Disarmament. Geneva, Switzerland: United Nations Institute for Disarmament Research p15-23. http://www.isn.ethz.ch/isn/Digital-Library/Publications/Detail/? ots591=0C54E3B3-1E9C-BE1E-2C24-A6A8C7060233\&lng=en\&id=47997

Riddick L, Thomson G, Wilson N, and Purdie G. 2008. Killing the canary: the international epidemiology of the homicide of media workers. Journal of Epidemiolgy \& Community Health 62:682-688.

Roberts L, Lafta R, Garfield R, Khudhairi J, and Burnham G. 2004. Mortality before and after the 2003 invasion of Iraq: cluster sample survey. Lancet 364:1857-1864.

RSF. 2012. Journalists killed Paris: Reporters Without Borders. http://en.rsf.org/

Taback N, and Coupland R. 2006. Security of journalists: Making the case for modelling armed violence as a means to promote human security. In: Borrie J, and Martin Randin V, editors. Thinking Outside the Box in Multilateral Disarmament and Arms Control Negotiations. Geneva, Switzerland: United Nations Institute for Disarmament Research. UNESCO. 2012. UNESCO Remembers Assassinated Journalists. United Nations Educational, Scientific and Cultural Organisation. Paris. 
345

346

347

348

349

350

351

352

http://www.unesco.org/new/en/communication-and-information/freedom-ofexpression/press-freedom/unesco-condemns-killing-of-journalists/

Wilson N, and Thomson G. 2007. Increase in violent deaths of Iraqi journalists since the 2003 invasion. Medicine, Conflict and Survival 23:145.

Zwi AB, Garfield R, and Loretti A. 2002. Collective violence. In: Krug E, Dahlberg LL, Mercy JA, Zwi AB, and Lozano R, editors. World Report on Violence and Health Geneva, Switzerland: World Health Organization. p 213-239. http://whqlibdoc.who.int/publications/2002/9241545615 eng.pdf 


\section{Table 1 (on next page)}

Table 1: Deaths of media workers in Iraq excluded from this analysis (2003-2012)

In the five databases reviewed, there were an additional 107 deaths of media workers that were excluded from our analysis. The major reasons for these exclusions were: (i) for 73 , the media worker death only being recorded in one of the five databases (68\%); (ii) for five, the individual not being definitively identified as being a media worker (5\%); (iii) for 16, not having any names identified (15\%); or (iv) for eight, only having one name identified (8\%). 
Table 1: Deaths of media workers in Iraq excluded from this analysis (2003-2012).

\begin{tabular}{|c|c|c|}
\hline Reason for exclusion & $\mathbf{N}$ & $\%$ \\
\hline Recorded in only one of the five databases & $73 *$ & $68 \cdot 2$ \\
\hline $\begin{array}{l}\text { Suspected media worker but not fully identified or name not } \\
\text { revealed }\end{array}$ & $16^{* *}$ & 150 \\
\hline Only first name or surname identified & $8 * * *$ & $7 \cdot 5$ \\
\hline $\begin{array}{l}\text { Not within our definition of a media worker occupation (see } \\
\text { Method) }\end{array}$ & 5 & 47 \\
\hline $\begin{array}{l}\text { Insufficient evidence that the death of the media worker was } \\
\text { in anyway related to being a media worker or } \\
\text { conducting their job as a media worker (e.g., may } \\
\text { have been other criminal activity such as robbery) }\end{array}$ & 4 & 37 \\
\hline No body recovered or no definitive proof of death & 1 & 09 \\
\hline Total & 107 & 100.0 \\
\hline
\end{tabular}

\footnotetext{
* RSF $n=23$. CPJ $n=20$, INSI $n=16$, IPI $n=7$, UNESCO $n=7$.

** INSI $n=12$, CPJ $n=4$

$* * *$ CPJ $\mathrm{n}=4$, INSI $\mathrm{n}=4$
}

Data sources: Data were collected for the ten-year period 2003-2012, from five online databases: Committee to Protect Journalists (CPJ), Reporters without Borders (RSF-Reporters Sans Frontières), United Nations Educational, Scientific and Cultural Organisation (UNESCO), the International News Safety Institute (INSI) and the International Press Institute (IPI). 


\section{Table 2 (on next page)}

Table 2: Details collected on violent deaths of media workers in Iraq (2003-2012).

The main associations and risk factors for the violent deaths of media workers in Iraq are presented for the ten-year time period (2003 to 2012) and for the two five-year time periods (2003 to 2007 and 2008 to 2012). 
Table 2: Details collected on violent deaths of media workers in Iraq (2003-2012).

\begin{tabular}{|c|c|c|c|c|c|c|}
\hline \multirow[t]{2}{*}{$\begin{array}{l}\text { Characteristic of the media } \\
\text { worker killed or event causing death }\end{array}$} & \multicolumn{2}{|c|}{ All } & \multicolumn{2}{|c|}{$\begin{array}{l}2003- \\
2007\end{array}$} & \multicolumn{2}{|c|}{$\begin{array}{l}2008- \\
2012\end{array}$} \\
\hline & $\mathbf{N}$ & $\%$ & $\mathbf{N}$ & $\%$ & $\mathbf{N}$ & $\%$ \\
\hline \multicolumn{7}{|l|}{ Sex } \\
\hline Male & 184 & $92 \cdot 5$ & 148 & $92 \cdot 5$ & 36 & $92 \cdot 3$ \\
\hline Female & 15 & $7 \cdot 5$ & 12 & $7 \cdot 5$ & 3 & $7 \cdot 7$ \\
\hline \multicolumn{7}{|l|}{ Age (years) } \\
\hline Mean & \multicolumn{2}{|c|}{$36 \cdot 5$} & \multicolumn{2}{|c|}{$37 \cdot 0$} & \multicolumn{2}{|c|}{$34 \cdot 8$} \\
\hline Median & \multicolumn{2}{|c|}{$35 \cdot 0$} & \multicolumn{2}{|c|}{$35 \cdot 0$} & \multicolumn{2}{|c|}{$30 \cdot 0$} \\
\hline Range & \multicolumn{2}{|c|}{$18-75$} & \multicolumn{2}{|c|}{$22-67$} & \multicolumn{2}{|c|}{$18-75$} \\
\hline \multicolumn{7}{|l|}{ Nationality } \\
\hline Iraqi & 169 & 84.9 & 132 & $82 \cdot 5$ & 37 & 94.9 \\
\hline Non-Iraqi & 30 & $15 \cdot 1$ & 28 & $17 \cdot 5$ & 2 & $5 \cdot 1$ \\
\hline \multicolumn{7}{|c|}{ Nationality of media worker if not Iraqi (where known) } \\
\hline $\mathrm{OECD}^{1}$ & 8 & $57 \cdot 1$ & 8 & $66 \cdot 7$ & 0 & 0 \\
\hline Other $^{2}$ & 6 & $42 \cdot 9$ & 4 & $33 \cdot 3$ & 2 & $100 \cdot 0$ \\
\hline \multicolumn{7}{|l|}{ Employer nationality (country details) } \\
\hline Iraq & 124 & $62 \cdot 3$ & 92 & $57 \cdot 5$ & 32 & $82 \cdot 1$ \\
\hline $\mathrm{OECD}^{3}$ & 49 & $24 \cdot 6$ & 47 & $29 \cdot 4$ & 2 & $5 \cdot 1$ \\
\hline Middle Eastern Country ${ }^{4}$ & 26 & $13 \cdot 1$ & 21 & $13 \cdot 1$ & 5 & $12 \cdot 8$ \\
\hline \multicolumn{7}{|l|}{ Specific media occupation } \\
\hline Media presenter ${ }^{5}$ & 100 & $50 \cdot 3$ & 74 & $46 \cdot 3$ & 26 & $66 \cdot 7$ \\
\hline Camera operator & 38 & $19 \cdot 1$ & 30 & $18 \cdot 8$ & 8 & $20 \cdot 5$ \\
\hline Editor / Deputy editor & 28 & $14 \cdot 1$ & 24 & $15 \cdot 0$ & 4 & $10 \cdot 3$ \\
\hline Producer & 8 & $4 \cdot 0$ & 8 & $5 \cdot 0$ & 0 & 0 \\
\hline Photographer & 7 & $3 \cdot 5$ & 7 & $4 \cdot 4$ & 0 & 0 \\
\hline Director / Head & 5 & $2 \cdot 5$ & 4 & $2 \cdot 5$ & 1 & $2 \cdot 6$ \\
\hline Interpreter / Translator & 6 & $3 \cdot 0$ & 6 & $3 \cdot 8$ & 0 & 0 \\
\hline Sound operator & 5 & $2 \cdot 5$ & 5 & $3 \cdot 1$ & 0 & 0 \\
\hline Other $^{6}$ & 2 & $1 \cdot 0$ & 2 & $1 \cdot 3$ & 0 & 0 \\
\hline \multicolumn{7}{|l|}{ Medium worked in } \\
\hline Television & 103 & $51 \cdot 8$ & 78 & $48 \cdot 7$ & 25 & $64 \cdot 7$ \\
\hline Print Media & 82 & $41 \cdot 2$ & 72 & $44 \cdot 9$ & 10 & $25 \cdot 6$ \\
\hline Radio & 7 & $3 \cdot 5$ & 6 & $3 \cdot 8$ & 1 & $2 \cdot 6$ \\
\hline Online news agency & 7 & $3 \cdot 5$ & 4 & $2 \cdot 5$ & 3 & $7 \cdot 7$ \\
\hline Means of death & & & & & & \\
\hline Gunfire & 135 & $67 \cdot 8$ & 111 & $69 \cdot 4$ & 24 & $61 \cdot 5$ \\
\hline Bomb (suicide) ${ }^{7}$ & 15 & $7 \cdot 5$ & 11 & $6 \cdot 9$ & 4 & $10 \cdot 3$ \\
\hline Bomb (non-suicide, excluding vehicle bombs) & 12 & $6 \cdot 0$ & 10 & $6 \cdot 3$ & 2 & $5 \cdot 1$ \\
\hline Grenade, missile or landmine & 9 & $4 \cdot 5$ & 9 & $5 \cdot 6$ & 0 & 0 \\
\hline Vehicle bomb & 9 & $4 \cdot 5$ & 1 & $0 \cdot 6$ & 8 & $20 \cdot 5$ \\
\hline Airstrike & 6 & $3 \cdot 0$ & 6 & $3 \cdot 8$ & 0 & 0 \\
\hline Other $^{8}$ & 13 & $6 \cdot 5$ & 12 & $7 \cdot 5$ & 1 & $2 \cdot 6$ \\
\hline Location of the death & & & & & & \\
\hline On assignment in the field & 77 & $38 \cdot 7$ & 63 & $39 \cdot 4$ & 14 & 35.9 \\
\hline Travelling (other than on assignment) & 47 & $23 \cdot 6$ & 38 & $23 \cdot 8$ & 9 & $23 \cdot 1$ \\
\hline Home & 23 & $11 \cdot 6$ & 16 & $10 \cdot 0$ & 7 & $17 \cdot 9$ \\
\hline Unknown & 21 & $10 \cdot 6$ & 17 & $10 \cdot 6$ & 4 & $10 \cdot 3$ \\
\hline Office & 10 & $5 \cdot 0$ & 10 & $6 \cdot 3$ & 0 & 0 \\
\hline Shop or market & 7 & $3 \cdot 5$ & 4 & $2 \cdot 5$ & 3 & $7 \cdot 7$ \\
\hline Drive by shooting & 4 & $2 \cdot 0$ & 4 & $2 \cdot 5$ & 0 & 0 \\
\hline Other $^{9}$ & 10 & $5 \cdot 0$ & 8 & $5 \cdot 0$ & 2 & $5 \cdot 1$ \\
\hline
\end{tabular}

Threats (preceding the violent death and to family or employers following it) $\begin{array}{lllllll}\text { None } & 100 & 50.3 & 94 & 58.8 & 6 & 15.4\end{array}$ 


\begin{tabular}{lrrrrrr}
\hline Characteristic of the media & \multicolumn{2}{c}{ All } & \multicolumn{2}{c}{$\mathbf{2 0 0 3 -}$} & \multicolumn{2}{c}{$\mathbf{2 0 0 8 -}$} \\
worker killed or event causing death & \multicolumn{4}{c}{$\mathbf{2 0 0 7}$} & $\mathbf{2 0 1 2}$ \\
\cline { 2 - 7 } & $\mathbf{N}$ & $\%$ & $\mathbf{N}$ & $\mathbf{\%}$ & $\mathbf{N}$ & $\%$ \\
\hline Unknown & 43 & $21 \cdot 6$ & 18 & $11 \cdot 3$ & 25 & $64 \cdot 1$ \\
Self/family & 34 & $17 \cdot 1$ & 26 & $16 \cdot 3$ & 8 & $20 \cdot 5$ \\
Employer & 14 & $7 \cdot 0$ & 14 & $8 \cdot 8$ & 0 & 0 \\
Both (self/family and employer) & 8 & $4 \cdot 0$ & 8 & $5 \cdot 0$ & 0 & 0 \\
Taken captive & & & & & & \\
Unknown & 110 & $55 \cdot 3$ & 84 & $52 \cdot 5$ & 26 & $66 \cdot 7$ \\
No & 64 & $32 \cdot 2$ & 56 & $35 \cdot 0$ & 8 & $20 \cdot 5$ \\
Yes & 25 & $12 \cdot 6$ & 20 & $12 \cdot 5$ & 5 & $12 \cdot 8$ \\
Tortured & & & & & & \\
Unknown & 111 & $55 \cdot 8$ & 85 & $53 \cdot 1$ & 26 & $66 \cdot 7$ \\
No & 79 & $39 \cdot 7$ & 67 & $41 \cdot 9$ & 12 & $30 \cdot 8$ \\
Yes & 9 & $4 \cdot 5$ & 8 & $5 \cdot 0$ & 1 & $2 \cdot 6$ \\
Perpetrators of the violence & & & & & & \\
Political group & 89 & $44 \cdot 7$ & 75 & $46 \cdot 9$ & 14 & $35 \cdot 9$ \\
Unknown & 58 & $29 \cdot 1$ & 43 & $26 \cdot 9$ & 15 & $38 \cdot 5$ \\
Coalition forces & 18 & $9 \cdot 0$ & 17 & $10 \cdot 6$ & 1 & $2 \cdot 6$ \\
Militia & 15 & $7 \cdot 5$ & 13 & $8 \cdot 1$ & 2 & $5 \cdot 1$ \\
Suicide attacker & 15 & $7 \cdot 5$ & 11 & $6 \cdot 9$ & 4 & $10 \cdot 3$ \\
Other ${ }^{10}$ & 4 & $2 \cdot 0$ & 1 & $0 \cdot 6$ & 3 & $7 \cdot 7$ \\
\hline
\end{tabular}

Data source: Data on the characteristics of the media worker killed or event causing death were collected for the ten-year period 2003-2012, from five online databases: Committee to Protect Journalists (CPJ), Reporters without Borders (RSF-Reporters Sans Frontières), United Nations Educational, Scientific and Cultural Organisation (UNESCO), the International News Safety Institute (INSI) and the International Press Institute (IPI)

${ }^{1}$ OECD = Organisation for Economic Co-operation and Development. United Kingdom ( $\left.\mathrm{n}=2\right)$, Japan ( $\left.\mathrm{n}=2\right)$, United States of America $(\mathrm{n}=1)$, Germany $(\mathrm{n}=1)$, Italy $(\mathrm{n}=1)$, Poland $(\mathrm{n}=1)$

${ }^{2} \operatorname{Iran}(\mathrm{n}=3)$, Palestine $(\mathrm{n}=1)$, Russia $(\mathrm{n}=1)$, Algeria $(\mathrm{n}=1)$

${ }^{3}$ OECD $=$ Organisation for Economic Co-operation and Development. United States of America $(n=19)$, United Kingdom ( $n=17)$, Japan ( $n=3)$, Germany ( $n=3)$, Spain ( $n=2)$,

Poland ( $\mathrm{n}=2)$, Australia $(\mathrm{n}=1)$, Czech Republic $(\mathrm{n}=1)$, Italy $(\mathrm{n}=1)$,

${ }^{4}$ Saudi Arabia ( $\left.n=5\right)$, Qatar ( $\left.n=4\right)$, Egypt ( $(n=3)$, Iran ( $\left.n=3\right)$, Lebanon ( $\left.n=3\right)$, United Arab Emirates ( $\left.n=3\right)$, Kuwait $(\mathrm{n}=2)$, Palestine $(\mathrm{n}=2)$, Dubai $(\mathrm{n}=1)$

${ }^{5}$ Reporter, correspondent, broadcaster or news presenter

${ }^{6}$ Academic $(\mathrm{n}=1)$, Owner $(\mathrm{n}=1)$

${ }^{7}$ One suicide bomb was also a vehicle bomb (but categorised here as suicide bomb)

${ }^{8}$ Throat slit ( $\left.\mathrm{n}=3\right)$, Beheading $(\mathrm{n}=1)$, Assault $(\mathrm{n}=1)$, Torched $(\mathrm{n}=1)$, Unknown $(\mathrm{n}=7)$

${ }^{9}$ Military base $(\mathrm{n}=2)$, Mosque $(\mathrm{n}=2)$, University $(\mathrm{n}=2)$, Hotel $(\mathrm{n}=1)$, Internet café $(\mathrm{n}=1)$, Outside relative's house $(\mathrm{n}=1)$, Walking in the centre of town $(\mathrm{n}=1)$

${ }^{10}$ Government officials $(n=2)$, Military intelligence agents $(n=1)$, Criminals $(n=1)$ 


\section{Table 3 (on next page)}

Table 3: Ratio of violent civilian deaths to violent media worker deaths.

The number of violent civilian deaths per violent media worker deaths increased from 412 (95\% Cl: $284-597)$ in 2004 to 1276 (95\% Cl: 479 - 3400) in 2009 where it peaked. 
Table 3: Ratio of violent civilian deaths to violent media worker deaths.

\begin{tabular}{ccccc}
\hline Year & $\begin{array}{c}\text { Civilian } \\
\text { deaths (n) }\end{array}$ & $\begin{array}{c}\text { Media worker } \\
\text { deaths (n) }\end{array}$ & $\begin{array}{c}\text { Ratio of civilian to } \\
\text { media worker } \\
\text { deaths }\end{array}$ & $\begin{array}{c}\text { 95\% confidence } \\
\text { intervals of ratio } \\
\text { of civilian to } \\
\text { media worker } \\
\text { deaths }\end{array}$ \\
\hline $\mathbf{2 0 0 3}$ & 12,093 & 15 & & $(486-1338)$ \\
$\mathbf{2 0 0 4}$ & 11,540 & 28 & 806 & $(284-597)$ \\
$\mathbf{2 0 0 5}$ & 16,161 & 28 & 412 & $(398-836)$ \\
$\mathbf{2 0 0 6}$ & 29,054 & 42 & 577 & $(511-936)$ \\
$\mathbf{2 0 0 7}$ & 25,316 & 47 & 692 & $(405-717)$ \\
$\mathbf{2 0 0 8}$ & 9639 & 14 & 539 & $(408-1163)$ \\
$\mathbf{2 0 0 9}$ & 5102 & 4 & 689 & $(479-3400)$ \\
$\mathbf{2 0 1 0}$ & 4109 & 7 & 1276 & $(280-1232)$ \\
$\mathbf{2 0 1 1}$ & 4147 & 9 & 587 & $(240-886)$ \\
$\mathbf{2 0 1 2}$ & 4573 & 5 & 461 & $(381-2198)$ \\
$\mathbf{2 0 0 3 - 2 0 0 7}$ & 94,164 & 160 & 915 & $(504-687)$ \\
$\mathbf{2 0 0 8 - 2 0 1 2}$ & 27,570 & 39 & 589 & $(516-968)$ \\
\hline
\end{tabular}

Data sources: Civilian death counts were collected from the Iraq Body Count "Documented civilian deaths from violence 2003-2012" http://www.iraqbodycount.org/. Media worker death counts were collected for the ten-year period 2003-2012, from five online databases: Committee to Protect Journalists (CPJ), Reporters without Borders (RSF-Reporters Sans Frontières), United Nations Educational, Scientific and Cultural Organisation (UNESCO), the International News Safety Institute (INSI) and the International Press Institute (IPI) 


\section{Table 4 (on next page)}

Table 4: Timeline of major events and violent deaths of media workers and others killed or injured in the same attack and deaths of other populations in Iraq (2003-2012).

Over the ten-year period, a total of 511 civilians were reported as killed in the same attacks in which a media worker died, and another 426 were non-fatally injured. The peak years of media worker violent deaths coincide with the years of the highest levels of violence in Iraq (2006 and 2007) when explosive incidents were at their height. 
Table 4: Timeline of major events and violent deaths of media workers and others killed or injured in the same attack and deaths of other populations in Iraq (2003-2012).

\begin{tabular}{|c|c|c|c|c|c|c|}
\hline Year & $\begin{array}{l}\text { Major socio-political events and selected economic } \\
\text { indicators }\end{array}$ & $\begin{array}{l}\text { Violent deaths } \\
\text { of media } \\
\text { workers }(\mathbf{N})\end{array}$ & $\begin{array}{l}\text { Others killed in } \\
\text { the same attack } \\
\text { killing a media } \\
\text { worker(N) }\end{array}$ & $\begin{array}{l}\text { Others } \\
\text { injured (non- } \\
\text { fatally) in the } \\
\text { same } \\
\text { attack(N) } \\
\end{array}$ & $\begin{array}{l}\text { Civilian } \\
\text { deaths } \\
\text { from } \\
\text { violence } \\
(\mathbf{N}) \\
\end{array}$ & $\begin{array}{l}\text { Homicides of } \\
\text { Iraqi military } \\
\text { and police }(\mathbf{N})\end{array}$ \\
\hline 2003 & $\begin{array}{l}\text { US-led invasion begins on } 19 \text { March. By } 9 \text { April much of } \\
\text { Baghdad is under US control. On } 1 \text { May US President } \\
\text { Bush declares militafy phase in Iraq has ended. On } 19 \\
\text { August, suicide bomber bombs UN headquarters in } \\
\text { Baghdad. On } 13 \text { December the former ruler of Iraq, } \\
\text { Saddam Hussein, is craptured by US soldiers. Post- } \\
\text { invasion, electricity production in Iraq is reported to be: } \\
\text { 3,500 megawatts, GDP: US } \$ 14 \text { billion, internet users: } \\
\text { 5000, telephone sub cribers: } 600,000 \text {. }\end{array}$ & 15 & 29 & 23 & 12,093 & 1300 \\
\hline 2004 & $\begin{array}{l}\text { On } 25 \text { January a former CIA inspector states that Iraq has } \\
\text { no illegal weapons April - May there is a month long } \\
\text { US military siege } \\
\text { formal sovereignty of Iraq to its new leaders. }\end{array}$ & 28 & 126 & 17 & 11,540 & \\
\hline 2005 & $\begin{array}{l}\text { Surge in vehicle bombings, bomb explosions and } \\
\text { shootings. }\end{array}$ & 28 & 23 & 6 & 16,161 & 2545 \\
\hline 2006 & Saddam Hussein tried and executed by Iraqi authorities. & 42 & 43 & 13 & 29,054 & 2091 \\
\hline 2007 & $\begin{array}{l}\text { A "surge" of } 30,000 \text { additional US troops enter Iraq. } \\
\text { Improvements are seen with electricity production: } 4000 \\
\text { megawatts, GDP: US } \$ 32 \text { billion, internet users: } 500,000 \text {, } \\
\text { and telephone subscribers: } 10 \text { million. }\end{array}$ & 47 & 150 & 194 & 25,316 & 1830 \\
\hline 2008 & Iraqi prime minister orders crackdown on militia in Basra. & 14 & 4 & 4 & 9639 & 1070 \\
\hline 2009 & $\begin{array}{l}\text { Iraq takes control of security in Baghdad's fortified Green } \\
\text { Zone and assumes more powers over foreign troops. Al- } \\
\text { Qaeda linked group "Islamic State of Iraq" claim } \\
\text { responsibility for a wave of suicide bombings in Baghdad. }\end{array}$ & 4 & 30 & 6 & 5102 & 515 \\
\hline 2010 & $\begin{array}{l}\text { Parliamentary elections are held. The last US combat } \\
\text { brigade leaves Iraq. }\end{array}$ & 7 & 13 & 40 & 4109 & 468 \\
\hline
\end{tabular}




\begin{tabular}{|c|c|c|c|c|c|c|}
\hline Year & $\begin{array}{l}\text { Major socio-political events and selected economic } \\
\text { indicators }\end{array}$ & $\begin{array}{c}\text { Violent deaths } \\
\text { of media } \\
\text { workers }(\mathbf{N})\end{array}$ & $\begin{array}{c}\text { Others killed in } \\
\text { the same attack } \\
\text { killing a media } \\
\text { worker(N) }\end{array}$ & $\begin{array}{c}\text { Others } \\
\text { injured (non- } \\
\text { fatally) in the } \\
\text { same } \\
\text { attack(N) } \\
\end{array}$ & $\begin{array}{l}\text { Civilian } \\
\text { deaths } \\
\text { from } \\
\text { violence } \\
\text { (N) }\end{array}$ & $\begin{array}{l}\text { Homicides of } \\
\text { Iraqi military } \\
\text { and police }(\mathrm{N})\end{array}$ \\
\hline
\end{tabular}

2011 Nationwide protests ealling for reform and end to

corruption. The remaining US troops leave in December.

Further improvements are seen with electricity production:

6500 megawatts,

GDP: US \$108 billiơn, internet users: 2 million, telephone

subscribers: 22 milliph.

\begin{tabular}{|c|c|c|c|c|c|c|}
\hline 2012 & 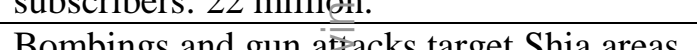 & 5 & 0 & 8 & 4573 & Not renorted \\
\hline$\frac{2012}{T 040}$ & Bombings and gun atracks target Shia areas. & $\frac{5}{100}$ & $\frac{0}{511}$ & $\frac{8}{126}$ & $\frac{45 / 3}{121724}$ & Not reported \\
\hline
\end{tabular}

Note - peak numbers of deaths in each category is bolded. The Iraq body Count includes police deaths among its' civilian death counts.

Data sources: Major socio-politica events were collected from the British Broadcasting Corporation (BBC) Iraq Profile http://www.bbc.co.uk/news/world-middle-east14546763 [Ref (BBC 2012)]. Serected economic indicators were collected from Livingston I, O'Hanlon ME, and Unikewicz A. 2011. States of Conflict: A Final Update. The New York Times 18 December hop://www.nytimes.com/2011/12/19/opinion/states-of-conflict-a-final-update.html [Ref (Livingston et al. 2011)]. Violent deaths of media workers and others killed and in i v ed in the same attacks iwere collected for the ten-year period 2003-2012, from five online databases: Committee to Protect Journalists (CPJ), Reporters without Bord er (RSF-Reporters Sans Frontières), United Nations Educational, Scientific and Cultural Organisation (UNESCO), the International News Safety Institute (INSI) and the International Press Institute (IPI). Civilian death counts were collected from the Iraq Body Count "Documented civilian deaths from violence 2003-2012” http://www.iraqbodycount.org/. Homicides of Iraqi military and police were collected from O'Hanlon ME, Livingston I (2011) Iraq Index. Tracking Variables of Reconstruction \& Security in Post-Saddam Iraq: Brookings Institution. http://www.brookings.edu/ /media/Centers/saban/iraq\%20index/index20101230.PDF [Ref

(O’Hanlon \& Livingston 2011)]. 


\section{Figure 1}

Figure 1: Annual trends in nationality of employer of media workers killed (Iraq 20022012)

The annual number of media worker violent deaths rose from 15 in 2003 to 47 in 2007 (the peak year) dropping back to 5 in 2012. The majority worked for Iraqi media agencies with this proportion increasing over time.

Data sources: Data were collected for the ten-year period 2003-2012, from five online databases: Committee to Protect Journalists (CPJ), Reporters without Borders (RSFReporters Sans Frontières), United Nations Educational, Scientific and Cultural Organisation (UNESCO), the International News Safety Institute (INSI) and the International Press Institute (IPI).

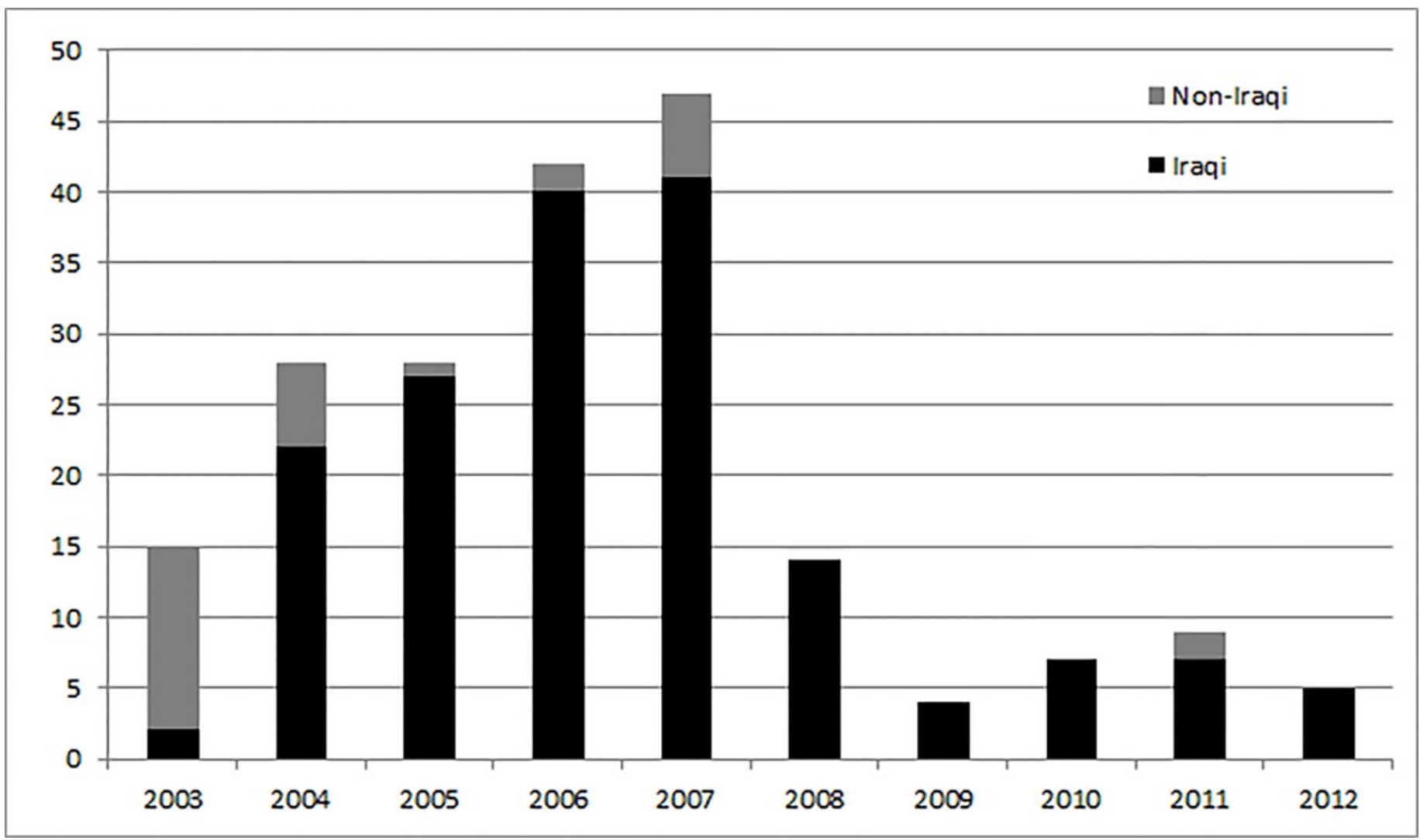




\section{Figure 2}

Figure 2: Annual trends in number of others killed and injured in the same attacks in which media workers died (Iraq 2003-2012).

Over the 10-year period, a total of 511 civilians were reported as killed in the same attack in which a media worker died. Furthermore, another 426 were injured in these attacks. The peak year of media worker violent deaths in 2007 matched the peak year of the number of others killed and injured in the same attacks.

Data sources: Data on media workers killed, others killed alongside and others injured alongside were collected for the ten-year period 2003-2012, from five online databases: Committee to Protect Journalists (CPJ), Reporters without Borders (RSF-Reporters Sans Frontières), United Nations Educational, Scientific and Cultural Organisation (UNESCO), the International News Safety Institute (INSI) and the International Press Institute (IPI).

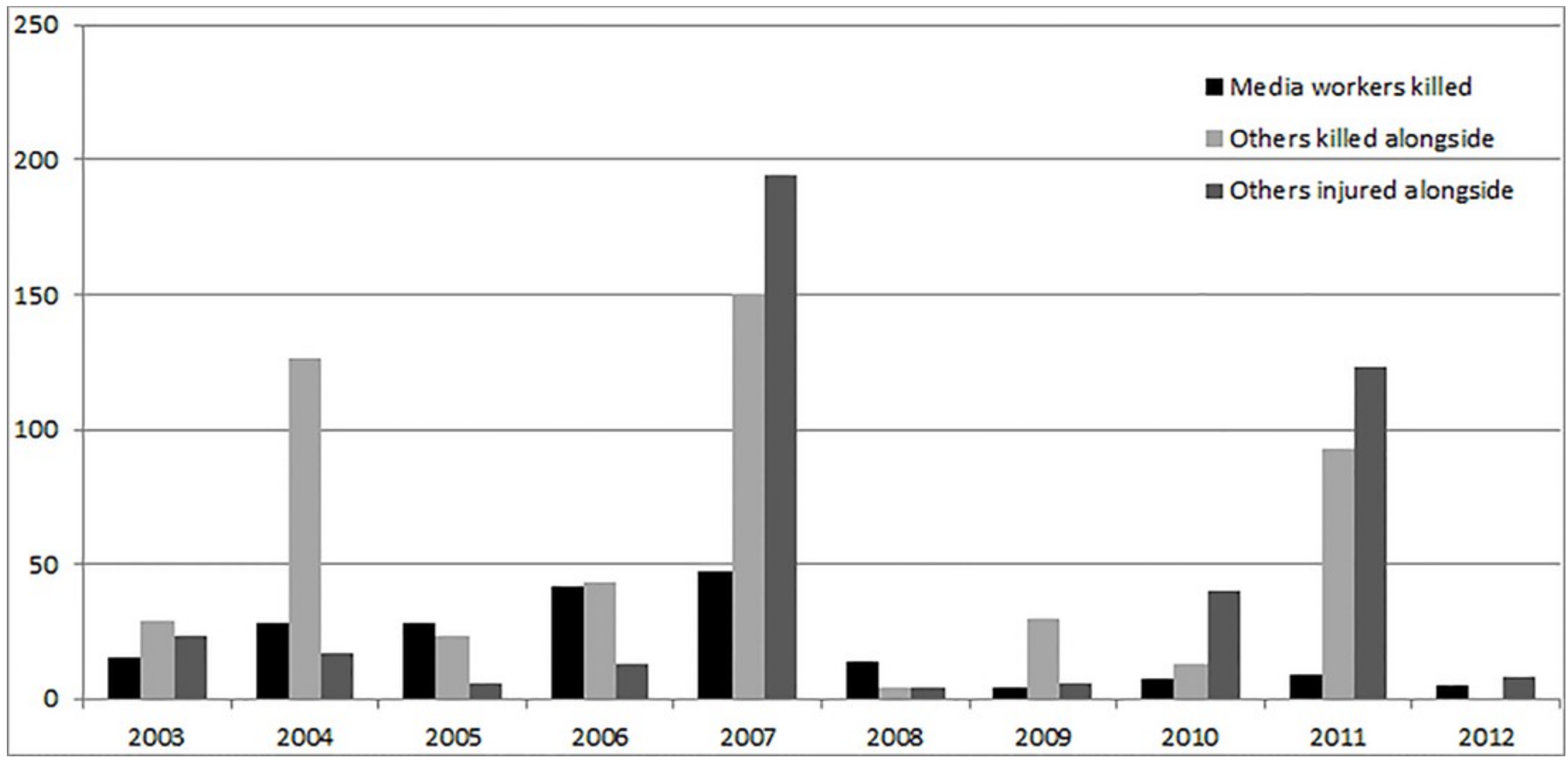




\section{Figure 3}

Figure 3: Civilian and media worker deaths from violence (Iraq 2003-2012).

The peak years (2006-2007) for media worker deaths from violence matched the peak years for estimated civilian fatalities (using counts of civilian deaths from violence from the Iraq Body Count).

Note: No media worker deaths from violence were recorded in Iraq in 2002 and no civilian deaths from violence were recorded by the Iraq Body Count in 2002. Thirteen media worker violent deaths were recorded for Iraq in 2013 in more than one of the five databases reviewed.

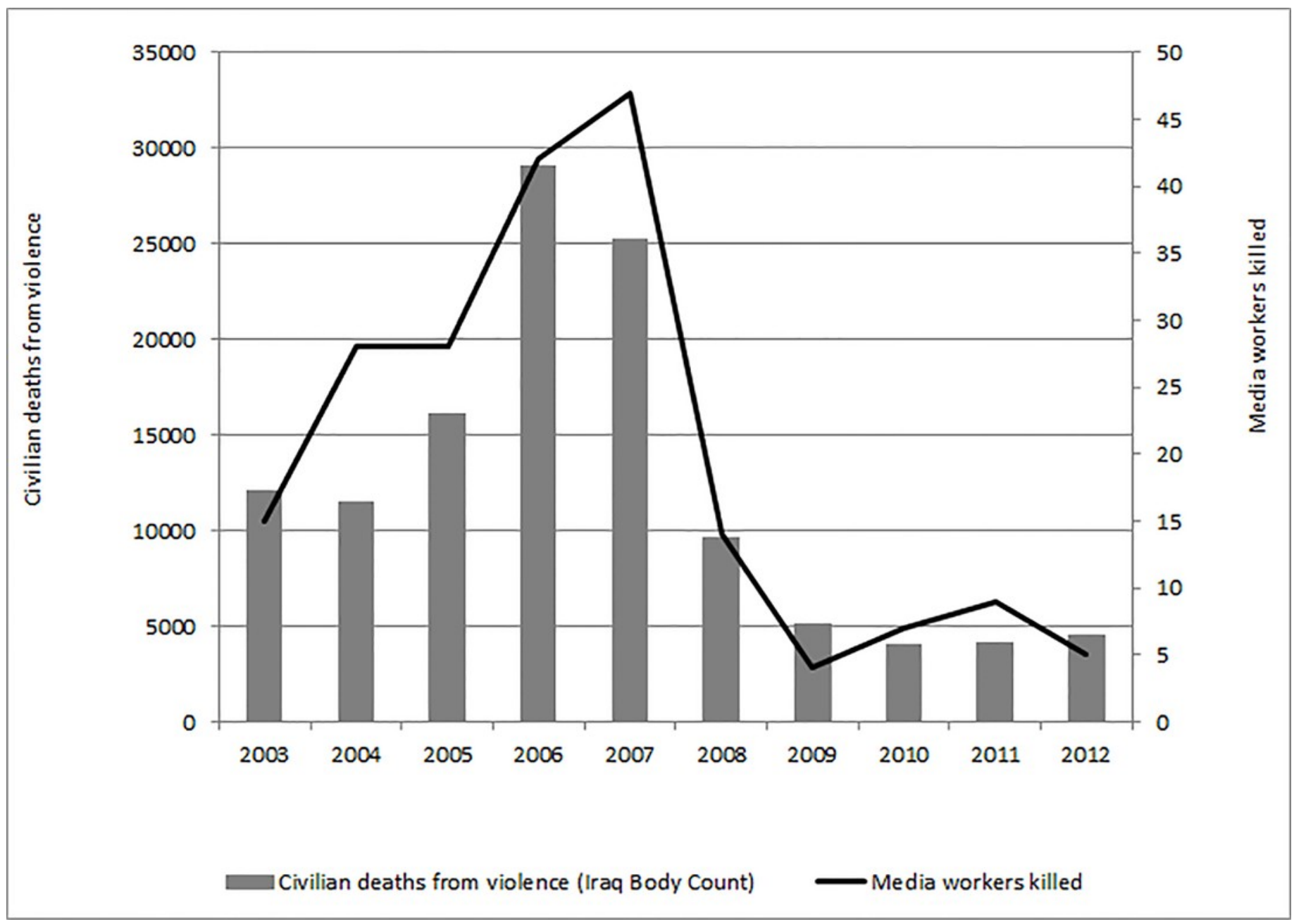

